\title{
Base Motives: The case for an increased focus on wage theft against migrant workers
}

\author{
Benjamin Harkins
}

\begin{abstract}
Since the adoption of the UN Trafficking Protocol, most of the efforts dedicated to eliminating exploitation of migrant workers have focused on human trafficking. Yet, there is limited evidence to show that this approach has been effective at reducing the scale or severity of abuses they experience. This article presents the case for increasing attention to a range of labour rights abuses falling under the category of wage theft. It considers the opportunities to shift the strategy for responding to exploitation, addressing the underlying pecuniary issues as a chief priority rather than as a matter of secondary concern. The analysis concludes that expanding engagement with the more 'mundane' vulnerabilities to abuse is essential to developing a pragmatic approach that enables migrants themselves to identify and denounce abuses. Interventions to prevent and remediate wage theft would contribute to better working conditions for the vast missing middle who experience more commonplace forms of abuse and help to diminish the enabling environment for severe exploitation to occur. Ensuring a more equitable distribution of wages would also redirect attention to a core issue at stake in the era of globalisation-the expansion of economic and social justice for migrant workers.
\end{abstract}

Keywords: wage theft, migrant worker, forced labour, human trafficking, modern slavery.

Please cite this article as: B Harkins, 'Base Motives: The case for an increased focus on wage theft against migrant workers', Anti-Trafficking Review, issue 15, 2020, pp. 42-62, https://doi.org/10.14197/atr.201220153.

This is an open-access article distributed under the terms of the Creative Commons Attribution License (CC-BY). Under the CC-BY license, the public is free to share, adapt, and make commercial use of the work. Users must always give proper attribution to the authors and the Anti-Trafficking Review. 


\section{Introduction}

The attention paid to exploitation within the global economy has never been greater. Since the adoption of the UN Trafficking Protocol, the lion's share of the efforts and resources have been focused on responding to human trafficking. Hundreds of millions of dollars are spent every year on counter-trafficking efforts, ${ }^{1}$ with a specific emphasis on investigation and criminal prosecution, raids to 'rescue' sex workers classified as potential victims, shelter and 'rehabilitation' services for survivors, and trainings to raise awareness among those who might experience or encounter human trafficking.

More recently, the emergence of the modern slavery discourse has emphasised the role of businesses in perpetuating the exploitation of workers. Against the background of a worldwide pursuit of ever cheaper labour and reduced regulation, more responsible practices by the private sector have been widely heralded as a force for change. ${ }^{2}$ In response, auditing of supply chains, certification regimes, and enactment of legislation that requires corporate disclosures on sourcing have increased dramatically. ${ }^{3}$ Non-binding 'commitments' to pay a living wage in supplier factories have been made by some of the world's largest garment companies, such as H\&M, Primark, and PVH. ${ }^{4}$

Technological solutions have also been posited as key to solving the problem of human trafficking. ${ }^{5}$ Models for expanding 'worker voice' have made use of smart phone apps to encourage migrants to report cases of exploitation. ${ }^{6}$

1 M Ucnikova, 'OECD and Modern Slavery: How much aid money is spent to tackle the issue?', Anti-Trafficking Review, issue 3, 2014, pp. 133-150, https://doi.org/10.14197/ atr.20121437.

2 A Gallagher, 'Four dangerous assumptions about human trafficking', World Economic Forum, 16 August 2017.

3 International Corporate Accountability Roundtable and Focus on Labour Exploitation, Full Disclosure: Towards better modern slavery reporting, London, 2019.

4 R Edwards, T Hunt, and G LeBaron, Corporate Commitments to Living Wages in the Garment Industry, University of Sheffield, 2019.

5 K Guilbert, 'UK Royal, US Ambassador Tout Tech Tools to Tackle Human Trafficking', Reuters, 9 April 2019, retrieved 31 July 2020, https://www.reuters.com/article/usglobal-trafficking-technology/uk-royal-us-ambassador-tout-tech-tools-to-tacklehuman-trafficking-idUSKCN1RK2C1.

6 L Rende Taylor and E Shih, 'Worker Feedback Technologies and Combatting Modern Slavery in Global Supply Chains', Journal of the British Academy, vol. 7, issue s1, 2019, pp. 131-165, https://doi.org/10.5871/jba/007s1.131. 
Satellite imagery has been employed to attempt to identify modern slavery situations from space through locating brick kilns. ${ }^{7}$ Blockchain technology has been trumpeted as a potential solution to problems with contract substitution. ${ }^{8}$ Big data is presented as a means for improving the evidence base for interventions to counter trafficking in persons. ${ }^{\text {? }}$

Yet, there is still limited evidence to show that these efforts have been effective. ${ }^{10}$ The quality of empirical data available to justify anti-trafficking initiatives has lagged behind their ever-expanding scope. Due to the lack of rigorous evidence of a long-term impact, the rhetoric and hyperbole of anti-trafficking organisations continue to escalate to present a compelling case for additional funding and support. Anachronistically referencing the abolitionist movements of prior centuries, their beneficiaries are now described as having been 'liberated from slavery' in some cases. ${ }^{11}$

Many of these initiatives have specifically targeted migrant workers due to their heightened vulnerability to severe forms of exploitation. However, there is reason to believe that less acute abuses are much more common and have even become normalised in some contexts. For example, a recent study in Australia found that nearly half of all migrant workers were paid below the legal minimum wage. ${ }^{12}$ These 'everyday' abuses have received much less attention in recent years. The relevant international labour standard, the Protection of Wages Convention, 1949 (No. 95), has become so outdated that it includes articles prohibiting 'payment of wages in taverns'. Nevertheless, estimates of the scale of wage violations suggest that they are one of the most significant forms of labour exploitation, costing low-wage workers USD 50

7 D Boyd et al., 'Slavery from Space: Demonstrating the role for satellite remote sensing to inform evidence-based action related to UN SDG number 8', Journal of Photogrammetry and Remote Sensing, vol. 142, 2018, pp. 380-388, https://doi.org/10.1016/j. isprsiprs.2018.02.012.

8 G Chavez-Dreyfuss, 'Coca-Cola, U.S. State Dept to use blockchain to combat forced labor', Reuters, 17 March 2018, retrieved 31 July 2020, https://www.reuters.com/ article/us-blockchain-coca-cola-labor/coca-cola-u-s-state-dept-to-use-blockchain-tocombat-forced-labor-idUSKCN1GS2PY.

$9 \quad$ T Sneed, 'How Big Data Battles Human Trafficking', U.S. News \& World Report, 14 January 2015, https://www.usnews.com/news/articles/2015/01/14/how-big-datais-being-used-in-the-fight-against-human-trafficking.

10 B Harkins, 'Constraints to a Robust Evidence Base for Anti-Trafficking Interventions', Anti-Trafficking Review, issue 8, 2017, pp. 113-130, https://doi.org/10.14197/atr. 20121787.

11 Ibid.

12 L Berg and B Farbenblum, Wage Theft in Australia: Findings of the National Temporary Migrant Work survey, University of New South Wales, 2017. 
billion per year in the United States alone. ${ }^{13}$

This article examines the case for an increased focus on financial abuses against migrant workers under the rubric of 'wage theft'. It presents the key arguments for an emphasis on wage-related violations, including the structural vulnerabilities created by restrictive migration governance regimes, the unsuitability of the human trafficking and modern slavery frameworks for resolving these abuses, and the necessity of developing a more pragmatic approach to counter exploitation. The analysis concludes by considering strategies for shifting the response to the exploitation of migrants, addressing the underlying pecuniary issues as a chief priority rather than as a matter of secondary concern.

The article is based on a review of the relevant academic and practice-oriented resources and also draws on primary data collected on complaint cases for the report Access to Justice for Migrant Workers in Southeast Asia. ${ }^{14}$ The findings were validated and improved through a review by several leading experts working in the fields of labour migration and anti-trafficking.

\section{Many Forms of Wage Theft are Neglected}

Although there is no internationally accepted definition of the concept of wage theft, it can be conceived as an amalgamation of a number of different types of labour rights abuses related to the denial of remuneration or benefits to a worker to whom they are owed or entitled. Not all forms of wage theft are considered to be indicative of forced labour or human trafficking, particularly those which are financially extractive but not explicitly coercive in nature (e.g. wages below the legal minimum or misclassification of employment). However, outright coercion or deception by employers may be unnecessary in contexts where migrants' rights are heavily restricted and few alternative livelihoods are available. This has created a practical gap in the legal and institutional frameworks addressing exploitation of migrants in many countries, where more routine wage abuses are often neglected or marginalised.

Descriptions of some of the more common types of wage theft committed against migrant workers and their relationship to ILO guidance on indicators of forced labour are provided below:

13 C McNicholas, Z Mokhiber, and A Chaikof, 'Two billion dollars in stolen wages were recovered for workers in 2015 and 2016-and that's just a drop in the bucket', Economic Policy Institute, 13 December 2017.

14 B Harkins and M Åhlberg, Access to Justice for Migrant Workers in Southeast Asia, ILO, Bangkok, 2017. 
Non-payment of wages: Not providing the full remuneration due for work performed at the end of a pay period. It is accepted to be an indicator of forced labour if the abuse is carried out in a 'deliberate and systematic manner'. ${ }^{15}$ In such cases, non-payment is considered a form of coercion, with migrant workers unable to leave their employment due to wages owed.

Lack of overtime pay: Not paying, or not paying at a higher rate, for working hours that extend beyond the standard length of work day or week. It is a common form of abuse against migrant workers as they frequently are required to work long hours and may have difficulty determining when they are entitled to overtime pay. While excessive overtime is recognised as an indicator of forced labour, lack of overtime pay in itself is not considered to be sufficient. ${ }^{16}$

Wages below the legal minimum: Payment of wages at a level that does not meet statutory requirements. Enforcement is typically more limited for migrant workers and they are more commonly employed in informal sectors which are exempted from minimum wage requirements. They also frequently receive wages determined by piece work, a share system (e.g. share of the catch in fishing), or gratuities, which heightens the risk of under-payment. Not paying the minimum wage is not acknowledged to be an indicator of forced labour, though receiving very low levels of remuneration clearly constrains the mobility and welfare of migrants.

Illegal wage deductions: Deduction from the pay of migrant workers for various costs and fees that are not permitted under law, including charging for fraudulent expenses, applying exorbitant rates, or passing on costs meant to be borne by employers. These abuses are often difficult to identify as a wide variety of deductions are typically permitted-including recruitment and migrationrelated costs - and there may be a lack of transparency about the charges or balances due. Wage deductions are only considered an indicator of forced labour to the extent that they constitute 'debt bondage', though the distinction is not entirely clear. ${ }^{17}$

Non-provision of benefits: Not making required contributions to social protection schemes or providing direct benefits such as housing or paid leave that are stipulated under law. In particular, many employers avoid making compulsory payments for social security, healthcare, or compensation for workplace accidents due to lack of awareness of entitlements among migrant workers. These abuses are not formally recognised as an indicator of forced labour.

15 ILO, ILO Indicators of Forced Labour, ILO, Geneva, 2012.

16 Ibid.

17 Ibid. 
Discriminatory wage setting: Paying a different wage to workers doing the same job (or a job of equal value) but who differ with respect to a personal characteristic such as nationality, race, gender, or sexual orientation. Although there is substantial research showing that inequitable wages are widespread for certain demographic groups-particularly women and migrant workersproving that the differences are the result of discrimination is often challenging. ${ }^{18}$ Discriminatory pay practices are not interpreted to be an indicator of forced labour.

Misclassification of employment: The intentional mischaracterisation of a worker's employment status as a contractor to avoid payment of higher wages or provision of entitlements. An increasingly common form of wage theft with the growth of non-standard forms of work, misclassification can result in grave repercussions for migrant workers by muddying the statutory responsibilities of their employers. However, it is not considered to be indicative of forced labour.

\section{Wage Exploitation is a Key Motivation for Employing Migrant Workers}

Traditional macroeconomic push and pull models for understanding migration flows use wage differentials between countries of origin and destination as a core variable for explaining migration. These theories predict that the number of individuals who consider migration to be an optimal choice increases in relation to discrepancies in pay. ${ }^{19}$ Potential migrants are typically assumed to have the information available to accurately estimate the costs and benefits involved in migration and make a rational choice on whether to migrate.

Research has shown that these models are not borne out empirically and tend to be relatively poor predictors of international migration. ${ }^{20}$ They have been criticised for isolating individuals from the surrounding social and political forces influencing their decisions, including the extent to which governments attempt to facilitate or block migration.

18 ILO, Global Wage Report 2018/19: What lies behind gender pay gaps, ILO, Geneva, 2018; C Bartolucci, 'Understanding the Native-Immigrant Wage Gap Using Matched Employer-Employee Data: Evidence from Germany', ILR Review, vol. 67, no. 4, 2014, pp. 1166-1202, https://doi.org/10.1177/0019793914546300.

19 C Dustmann, 'Return Migration, Wage Differentials, and the Optimal Migration Duration', IZA Discussion Paper No. 264, Bonn, 2001.

20 F Cuamea Velázquez, 'Approaches to the Study of International Migration: A review', Estudios Fronterizos, vol. 1, no. 1, 2000, pp. 137-168, https://doi.org/10.21670/ ref.2000.01.a04. 
While the decisions of workers to migrate cannot be reduced to the wages on offer, the motivations for employers to recruit migrants are in many cases easier to comprehend. Within a globalised economy, choices about where to source or manufacture products are frequently based on the availability of low-cost labour and a permissive environment for industry. As opposed to migrant workers themselves who often have very limited information available, ${ }^{21}$ multinational companies conduct detailed assessments of labour markets and regulatory frameworks before making decisions about where and how to do business.

As labour is typically the largest cost of outsourced production, multinational firms actively comparison shop to find labour markets which offer the greatest reduction in worker wages. ${ }^{22}$ This creates enormous pressure on their upstream suppliers to constantly pursue lower labour costs, making the employment of migrant workers at exploitative pay levels close to an economic necessity. In labour intensive industries such as sugar cane, garments, chocolate, seafood and electronics, these market forces create business models which are only able to remain profitable due to various forms of wage theft. ${ }^{23}$

The recent expansion of corporate social responsibility initiatives has not been successful in addressing these labour abuses, ${ }^{24}$ and has had the effect of marginalising the plight of migrant workers outside global supply chains who are equally vulnerable. These efforts have sought to leverage a 'neoliberal ethics of the self', with the notion that abuses can be stopped through demands for greater corporate transparency and consumer activism. ${ }^{25}$ However, only workers whose conditions are highlighted by their proximity to markets in the Global North are understood to deserve attention, and the power is placed in the hands of consumers and corporations to effect change rather than workers themselves. ${ }^{26}$ Abuse of migrant workers in industries serving domestic markets is therefore rendered immaterial.

21 B Harkins, D Lindgren, and T Suravoranon, Risks and Rewards: Outcomes of labour migration in South-East Asia, ILO and IOM, Bangkok, 2017.

22 O Knack, 'Side-by-side: Top 4 Asian countries for manufacturing garments', Asia Quality Focus, 15 August 2017, retrieved 31 July 2020, https://www.intouch-quality. $\mathrm{com} / \mathrm{blog} /$ side-by-side-top-4-asian-countries-for-manufacturing-garments.

23 G LeBaron et al., Confronting Root Causes: Forced labour in global supply chains, openDemocracy and University of Sheffield, 2018, pp. 42-44.

24 Ibid.

25 S Molland, 'What Happened to Sex Trafficking? The new moral panic of men, boys and fish in the Mekong region', Sojourn: Journal of Social Issues in Southeast Asia, vol. 34, no. 2, 2019, pp. 397-424.

26 E Shih, 'Worker organising can counter labour abuse in the Global South', Al Jazeera, 8 January 2020. 
Migration for domestic work in Malaysia provides a case in point. In recent years, the Malaysian government has sought bilateral agreements with a growing number of countries to meet the demand for low-cost domestic services. This was necessary because Indonesia and Cambodia halted deployment of domestic workers to the country due to widespread reports of abuse. The impact of these bans was deeply felt in Malaysia as perceptions of a 'maid shortage' triggered deeper cultural anxieties about economic malaise. ${ }^{27}$ In response, Malaysia held bilateral talks with Bangladesh, Nepal, and Myanmar to expand the number of domestic workers available but did not offer coverage by the minimum wage. $^{28}$ Without government efforts to maintain exploitative wage levels, the vast majority of Malaysians would simply be unable to afford full-time domestic workers living in their homes.

\section{Restrictive Labour Migration Regimes Create Structural Vulnerabilities to Wage Theft}

The basic premise for admitting migrant workers to a destination country is typically to address a labour shortage in a particular sector or geographic region. If admission of migrants can hold down wages in these industries or areas, the economy is seen as benefitting from the increased supply of low-cost labour. At the same time, governments are under competing pressure to prevent the wages of local workers from being depressed. Therefore, regulatory procedures for admission and employment are established to channel migrant workers into the specific jobs to be filled to support complementarity rather than competition with national workers. ${ }^{29}$

To maintain these objectives, policies on temporary labour migration in destination countries typically provide very limited flexibility for migrant workers to change jobs of their own volition. Their legal status is usually directly tied to their employer, preventing them from leaving their employment without losing permission to stay and work. There are few examples within OECD countries where migrants are granted unrestricted access to the labour market and the opportunities in many Asian and Middle Eastern countries are even more limited. ${ }^{30}$

27 J Elias and J Louth, 'Producing Migrant Domestic Work: Exploring the everyday political economy of Malaysia's “maid shortage”, Globalizations, vol. 13, issue 6, 2016, pp. 830-845, https://doi.org/10.1080/14747731.2016.1155340.

28 B Harkins, Review of Labour Migration Policy in Malaysia, ILO, Bangkok, 2016.

29 M Abella and P Martin, Manual on Measuring Migration Policy Impacts in ASEAN, ILO, Bangkok, 2015.

30 S Kouba and N Baruah, Access to the Labour Market for Admitted Migrant Workers in Asia and Related Corridors, ILO, Bangkok, 2019. 
These restrictions on the ability of migrant workers to change employers can lead to structural vulnerabilities to abuse by creating a dependency that can easily be exploited. As elaborated by De Genova in his concept of 'deportability', the ever-present threat of expulsion has a disciplinary effect on the behaviour of migrant workers. ${ }^{31}$ They cannot easily leave situations of wage theft or register complaints without fear of retaliation and loss of legal status. In addition, the opportunity for migrants to organise into trade unions for collective bargaining is restricted within many destination countries, either by law or in practice. ${ }^{32}$ Because of this imbalance of power within the employment relationship, migrant workers often have limited ability to negotiate over wages or benefits.

With these enabling factors in place, wage theft cannot be regarded as an unintended consequence of restrictive labour migration governance regimes. Systematic measures to decrease the ability of migrant workers to avoid, seek redress, or leave abusive situations have a calculated recoupment effect on wage payments. It has been argued that the cost of migrants' rights is in fact directly priced into the formulation of migration policies in destination countries. ${ }^{33}$ Therefore, a rebalancing requires expanding the power of workers to demand fair wages and benefits and obtain satisfactory financial remedies if they are not provided.

\section{Lack of Coverage by Wage Protection Enables Discriminatory Pay Practices}

Migrant workers are more commonly employed in informal sectors of work which are not fully covered by labour laws than nationals. ${ }^{34}$ As a result, they are exempted from key wage protections such as a legal minimum or overtime pay. This contributes to artificially low wages and segmentation within national labour markets. A substantial body of evidence shows that workers in the informal economy are among the most vulnerable to labour rights abuses due to their exclusion from these legal protections. ${ }^{35}$

31 N P De Genova, 'Migrant "Illegality" and Deportability in Everyday Life', Annual Review of Anthropology, vol. 31, no. 1, 2002, pp. 419-447, https://doi.org/10.1146/ annurev.anthro.31.040402.085432.

32 ILO, Addressing Governance Challenges in a Changing Labour Migration Landscape, ILO, Geneva, 2017.

33 M Ruhs, The Price of Rights: Regulating international labor migration, Princeton University Press, Princeton, 2013.

34 N Popova and M H Özel, Global Estimates on International Migrant Workers, ILO, Geneva, 2018.

35 ILO, Ending Forced Labour by 2030: A review of policies and programmes, ILO, Geneva, 2018. 
Globally, migrant domestic workers are recognised as facing some of the most abusive pay practices, including withholding, non-payment, and underpayment of wages. $^{36}$ Just as women are typically expected to do the majority of the household work without pay, migrant domestic workers-who are predominantly women - are expected to work for little pay. This reflects a devaluing of the occupation because it is traditionally viewed as an inherent responsibility of women rather than a form of work. Domestic workers are commonly expected to put in excessively long hours without overtime pay or paid leave since they are considered to be 'part of the family' rather than legitimate workers requiring formal labour and social protections. ${ }^{37}$

The fragmentation of employment relationships in recent decades has also led to a decline in wage protections within sectors that employ migrant workers. Research on migrant construction work in the Middle East has shown that delayed payment and wage theft are widespread; linked to obsolete payment systems that have not kept pace with the growth of non-standard forms of work. ${ }^{38}$ Due to externalised working arrangements through outsourcing and temporary staffing agencies, the main employers of the migrant workforce often have less legal responsibility for the pay and benefits they provide. At the same time, increasingly competitive bidding for construction project tenders has ratcheted up pressure to reduce labour costs through any means necessary, including sub-legal wage levels, non-payment of wages, and misclassification of employment.

Even in sectors where high-profile steps have been taken to formalise the employment of migrant workers to ensure fair wages, enforcement often continues to fall short. In Thailand, for example, migrants make up the vast majority of workers in the USD 6 billion fishing industry, which has faced intense pressure to reform in recent years due to reports of severe abuses. In response, the Thai government made substantial efforts to amend its legislative frameworks to provide fishers with expanded labour protections, as they had previously been excluded from many of the labour rights afforded to workers in other sectors. However, recent research by the International Labour Organization (ILO) shows that systematic abuses against migrants persist and continue to be most commonly related to payment of wages. ${ }^{39}$

36 E Menegatti, Protecting Migrant Domestic Workers: The international legal framework at a glance, ILO, Geneva, 2016.

37 B Anderson, Worker, Helper, Auntie, Maid? Working conditions and attitudes experienced by migrant domestic workers in Thailand and Malaysia, ILO, Bangkok, 2016.

38 J Wells, Protecting the Wages of Migrant Construction Workers, Engineers Against Poverty, London, 2016.

39 J Judd, S Chotikajan, and K Emmons, Baseline Research Findings on Fishers and Seafood Workers in Thailand, ILO, Bangkok, 2018. 
Part of the challenge in reinforcing labour protection for migrants is that deeply entrenched discriminatory attitudes cannot easily be legislated away. Research in Asia suggests that negative public perceptions have a strong impact on the application of laws regulating the wages of migrant workers. ${ }^{40}$ Authorities may react differently to cases of wage theft when they involve migrants as it is rationalised that they are still receiving better wages than they would in their countries of origin. In particular, officials may be less sympathetic towards undocumented migrant workers who are underpaid as they are viewed as having brought the problem upon themselves. ${ }^{41}$

\section{Wage Abuses Regularly Feature in Forced Labour and Human Trafficking}

Given the lack of reliable data on human trafficking and forced labour, there have been increased efforts to produce more robust macro-level estimates of prevalence. After several years of discursive competition between the two organisations, the ILO and Walk Free Foundation jointly produced the Global Estimates of Modern Slavery in 2017. However, researchers have continued to raise concerns about the validity of the methodological approach, noting problems with the limited source data to support extrapolation to the global level, the artifice created by dichotomising between free and forced labour, the uncomfortable fusing of forced marriage and forced labour, and other concerns. $^{42}$

Putting these important questions aside, the large primary dataset of the Global Estimates of Modern Slavery does provide some interesting findings on the labour rights abuses faced by workers. Though the study makes a distinction that is difficult to justify vis-à-vis international labour standards-between 'forced labour exploitation' and 'forced sexual exploitation'-it does reveal that the most common form of abuse within the former is related to wages. Among the estimated victims of forced labour exploitation, nearly one-third of victims were coerced through forms of wage theft, including non-payment of wages and financial penalties. This data does not fully capture the range of everyday abuses experienced by migrant workers but it does suggest that a large portion of even the most severe cases of exploitation are fundamentally linked to wage theft.

40 M Tunon and N Baruah, 'Public Attitudes towards Migrant Workers in Asia', Migration and Development, vol. 1, issue 1, 2012, pp. 149-162, https://doi.org/10.1080/2163232 4.2012.718524.

$41 \quad$ Ibid.

42 D Mügge, '40.3 Million Slaves? Four reasons to question the new Global Estimates of Modern Slavery', openDemocracy, 17 October 2017. 
An increasing number of sectoral studies are also being undertaken to assess the prevalence of forced labour in high-risk industries. The ILO released a survey of the Thai fishing sector in 2013, which identified a substantial number of fishers in conditions of forced labour and investigated the reasons why these situations occurred. This analysis contributed to an important change in understanding of the nature of exploitation in the fishing industry. High-profile media stories recounting how helpless migrants were deceived, drugged, or even physically forced to get on-board fishing boats and then taken out to sea were found to represent a very small portion of cases. In opposition to these narratives, the study found that nearly three-quarters of the workers experiencing forced labour were recruited willingly to work in fishing but had their wages withheld, preventing them from leaving until they were paid. ${ }^{43}$

One very direct source of data on the nature of exploitation experienced by migrant workers is the complaint cases they file with legal assistance providers. Since 2011, over 30 Migrant Worker Resource Centres (MRCs) have been set up in six countries across Southeast Asia to increase access to justice for migrant workers and provide other forms of assistance. The MRCs support migrants to seek remedies for abuses during recruitment and employment, including for cases of forced labour and trafficking.

As the MRC data became more robust, an action research project was initiated to make use of the improved evidence base. In total, primary data from over 1,000 complaints involving more than 7,000 migrant workers was analysed. More than half of the cases in destination countries were related to types of wage theft, including non-payment and underpayment of wages and wages below the legal minimum. This latter type of grievance was found to be particularly common for migrant workers, partially due to the enactment of highly publicised minimum wage legislation in Thailand and Malaysia. Establishing a clear statutory minimum provided an important means for migrant workers to assert their labour rights. ${ }^{44}$

A substantial portion of the complaints received by MRCs showed indications of forced labour, and many were explicitly identified as such by case managers. This suggests that efforts to identify more routine abuses are necessary to effectively identify and assist severely exploited migrants. Criminal justice responses to human trafficking are unlikely to be successful in addressing this need. This is partially because most migrants who are faced with situations of abuse tend to seek practical resolutions, such as disbursement of unpaid wages, rather than punitive sanctions for offenders. Inclusion of the right to pursue

43 S Chantavanich et al., Employment Practices and Working Conditions in Thailand's Fishing Sector, ILO, Bangkok, 2013.

44 Harkins and Åhlberg. 
financial remedies as a knock-on to criminal prosecutions has not proven very successful as it is not a function that criminal justice systems are typically wellequipped to handle. ${ }^{45}$

\section{Human Trafficking and Modern Slavery Frameworks are Ill-suited for Promoting Social Justice}

Despite the rhetoric about human trafficking being a non-partisan issue, research has shown that anti-trafficking responses are frequently politicised. ${ }^{46}$ A notable historical pattern has been the comfort with which conservative politicians and think tanks have adopted the issue to further their agendas. The Bush administration made trafficking a priority largely because it supported the promotion of the evangelical Christian position that all sex work is inherently coercive and must be abolished. ${ }^{47}$ This policy was linked to the larger moral goals of reinstating traditional gender roles, the sanctity of marriage, and heterosexual norms within American society, as well as extending these arrangements around the world. ${ }^{48}$ Though some efforts to establish a labour approach to antitrafficking were made during the Obama presidency, ${ }^{49}$ the puritanical fixation with 'sex trafficking' has proven to be an immutable feature of US policy.

More recently, the Heritage Foundation, a highly influential conservative think tank, has fought to keep attention on human trafficking within the Trump administration, recognising it as a key tool for promoting American foreign policy objectives. ${ }^{50}$ Their concerns appear largely unfounded as the Trump White House has avidly embraced the human trafficking cause. President Trump

45 N Wongsamuth, 'Thailand's human traffickers flout $99 \%$ of court orders to compensate victims', Reuters, 15 October 2019, retrieved 31 July 2020, https://www.reuters.com/ article/us-thailand-trafficking-compensation-exc/exclusive-thailands-humantraffickers-flout-99-of-court-orders-to-compensate-victims-idUSKBN1WU00P.

46 J A Chuang, 'Exploitation Creep and the Unmaking of Human Trafficking Law', American Journal of International Law, vol. 108, no. 4, 2014, pp. 609-649, https://doi. org/10.5305/amerjintelaw.108.4.0609.

47 Y C Zimmerman, 'Christianity and Human Trafficking', Religion Compass, vol. 5, issue 10, 2011, pp. 567-578, https://doi.org/10.1111/j.1749-8171.2011.00309.x.

48 Ibid.

49 D J Greuner, 'Counteracting the Bias: The Department of Labor's unique opportunity to combat human trafficking', Harvard Law Review, vol. 126, no. 4, 2013, pp. 1012-1033.

50 O Enos and M Lagon, 'The Fight against Human Trafficking is Too Important for Trump and Pompeo to Ignore', The Heritage Foundation, 4 June 2018, https: / www. heritage.org/civil-rights/commentary/the-fight-against-human-trafficking-tooimportant-trump-and-pompeo-ignore. 
has justified his policies militarising border management and dramatically expanding immigration enforcement by making repeated references to women being trafficked across the border from Mexico 'tied up, with duct tape on their faces, put in the backs of vans'. The rhetoric in no way reflects the circumstances of the vast majority of identified trafficking cases in the United States and is particularly ironic given that the administration has made it increasingly difficult for migrant trafficking survivors to seek visas and protection services to remain in the country. ${ }^{51}$

Staking its own claim within the anti-trafficking discourse, the United Kingdom has sought to reference its historical legacy in the abolitionist movement against slavery by supporting the rebranding of all forms of exploitation under the umbrella term 'modern slavery'. Former UK Prime Minister Theresa May promoted efforts to combat modern slavery as a key focus of her foreign policy agenda. However, the bitter taste left by these efforts in countries where the United Kingdom holds a violent and exploitative colonial legacy has not gone unnoticed by scholars. ${ }^{52}$ Moreover, implementing the policy while at the same time promoting a hostile environment towards migrants within its borders has only been reconciled through semantic obfuscation. The embrace of modern slavery language has been described as a 'discourse of depoliticization', raising the bar for what can be classified as unacceptable working conditions and absolving the state from responsibility for its role in creating the vulnerabilities that lead to exploitation, particularly for migrant workers..$^{53}$

The ease with which the human trafficking framework fits with a conservative political agenda suggests that it is largely unsuitable for promoting the expansion of economic and social justice for migrant workers. Extensive ratification of the UN Trafficking Protocol continues to be lauded for increasing global attention to exploitation. ${ }^{54}$ However, its framing of the issue as resulting from criminality has served as a convenient distraction from a global economic model reliant upon acceptance of an immensely uneven distribution of wealth. Rather than highlighting these structural inequalities, the trafficking discourse rationalises

51 J Krajeski, 'The Hypocrisy of Trump's Anti-Trafficking Argument for a Border Wall', The New Yorker, 5 February 2019, https://www.newyorker.com/news/news-desk/ the-hypocrisy-of-trumps-anti-trafficking-argument-for-a-border-wall.

52 S Okyere, "Fielding the wrong ball - culture as a cause of "modern slavery", openDemocracy, 8 October 2014, https://www.opendemocracy.net/en/beyondtrafficking-and-slavery/fielding-wrong-ball-culture-as-cause-of-modern-slavery.

53 B Anderson and R Andrijasevic, 'Sex, Slaves and Citizens: The politics of antitrafficking', Soundings, no. 40, 2008, pp. 135-145, https://doi.org/10.3898/ 136266208820465065.

54 A T Gallagher, 'Two Cheers for the Trafficking Protocol', Anti-Trafficking Review, issue 4, 2015, pp. 14-32, https://doi.org/10.14197/atr.20121542. 
exploitation of migrant workers to be an aberration, diverting attention from the more systemic changes to labour relations that are required.

\section{Need for a More Pragmatic Response to the Exploitation of Migrant Workers}

Problems with the lack of clarity on what constitutes human trafficking have been a major obstacle to identification since the UN Trafficking Protocol was first adopted. ${ }^{55}$ The three elements of 'act', 'means', and 'purpose' are inevitably interpreted in a range of different ways when applied in practice. In the real world, there is no easy opposition to be found between free and unfree labour. A binary separation of human trafficking from other forms of labour requires a judgement to be made about whether various conditions are considered exploitative or not, and what practices rise to the level of coercion, in a vast number of different contexts. ${ }^{56}$

Another obstacle to operationalising the concepts of forced labour, human trafficking, and modern slavery, is that they are too abstract for survivors to self-identify. As noted in the ILO's survey guidelines on forced labour: 'Selfidentification of victims of forced labour is not possible, mainly because the concept is too complex. Even in countries where campaigns have raised awareness of the issue using a specific terminology (such as "slave labour" in Brazil), it is not possible to rely on selecting respondents with a filter question using self-identification, as most victims do not recognize themselves as victims of forced labour or trafficking. ${ }^{57}$ The conceptual intricacies involved require that cases be identified by a third party, significantly limiting the agency of survivors themselves to denounce abuses. This has also contributed to a lopsided focus on exploitation in the sex industry due to moral panics created by some of the actors involved. ${ }^{58}$

55 Ibid.

56 J O’Connell Davidson, 'New Slavery, Old Binaries: Human trafficking and the borders of "freedom", Global Networks, vol. 10, issue 2, 2010, pp. 244-261, https://doi. org/10.1111/j.1471-0374.2010.00284.x.

57 ILO, Hard to See, Harder to Count: Survey guidelines to estimate forced labour of adults and children, ILO, Geneva, 2012.

58 E Bernstein, Brokered Subjects: Sex, trafficking, and the politics of freedom, University of Chicago Press, Chicago and London, 2018. 
Key to addressing a larger share of the abuses occurring is that migrants clearly understand when they have experienced a violation of their rights and are able to come forward to lodge a complaint. In that regard, wage-related abuses can be considered a much more straightforward offense than human trafficking. In many cases, basic numeracy skills would be sufficient for a migrant worker to understand when they do not receive the wages they were promised. While indirect forms of wage theft can be more complex, they are still not comparable with the cryptic process for identification of victims of trafficking. This requires application of loosely defined concepts such as 'exploitation', which is not provided within the UN Trafficking Protocol itself nor typically wellunderstood by trafficked persons or criminal justice officials. ${ }^{59}$

In addition, addressing wage theft does not sensationalise the abuse of migrant workers, which could contribute to more cases being lodged and remedied. Part of the problem with enforcing modern slavery legislation is that it has had the effect of increasing the threshold for what can be considered exploitation to dizzying heights. The concept carries with it such baggage in its connection with historical chattel slavery that it may be considered inappropriate to pursue such a case if the abuse is not extremely severe. While being found guilty of wage theft would certainly hold stigma for an employer, it does not carry the same risk of hyperbole in describing the abuse. Moreover, it does not force migrants to accept being branded a 'slave', a particularly sensitive term in countries which were directly affected by the historic phenomenon. ${ }^{60}$

\section{Effective Strategies to Reduce Wage Theft against Migrants are Available}

Unlike the enigmatic issue of human trafficking, proven approaches for addressing wage theft against migrant workers already exist. ${ }^{61}$ They only require the political will to shift the response to exploitation towards enabling a fairer distribution of income, rather than penalising criminal transgressions. Fundamentally, this involves increasing the power of migrant workers within their employment relationships so that they are less dependent on employers and can assert their rights to equitable wages and working conditions.

59 A T Gallagher and M McAdam, The Concept of 'Exploitation' in the Trafficking in Persons Protocol, UNODC, Vienna, 2015.

60 M Dottridge, 'Eight Reasons Why We Shouldn't Use the Term "Modern Slavery", openDemocracy, 17 October 2017.

61 DJ Galvin, 'Deterring Wage Theft: Alt-labor, state politics, and the policy determinants of minimum wage compliance', Perspectives on Politics, vol. 14, issue 2, 2016, pp. 324350, https://doi.org/10.1017/S1537592716000050. 
One clear starting place is ensuring that effective preventative measures against wage theft are enacted through labour protection laws. Establishing robust wage protections that apply equally to migrants, such as fair and inclusive minimum wage setting, rules on regularity of pay, limitations on allowable wage deductions, requiring written pay slips/electronic payments, addressing discriminatory pay practices, adopting chain liability rules, and protecting workers from retaliatory dismissal are proven regulatory means for reducing wage theft. In the State of New Jersey, for instance, a Wage Theft Act was recently passed which requires the provision of a written statement of wage rights and stipulates that any disciplinary action taken against a worker within 90 days of filing a complaint is presumptively considered retaliation. Under Brazil's Labour Code, contractors can be held accountable for wage violations committed by their sub-contractors based upon a system of joint liability. ${ }^{62}$

Extending social protection coverage to all migrant workers is also needed to provide a financial safety net so that they can leave situations of wage theft. Social security systems around the world were typically designed to provide protection to workers on a territorial basis. As a rule, they have not been sufficiently adapted to the changes in global labour markets that have increased the volume and impermanence of labour migration across international borders. As a consequence, many of the eligibility requirements to receive benefits either explicitly exclude or create significant obstacles for migrants to avail themselves of their rights (e.g. citizenship, legal documentation, minimum qualifying periods, and sectoral exclusions). When compounded by common problems with compliance, a large proportion of migrants are left without access to protection and are vulnerable when faced with a sudden loss of income. ${ }^{63}$

Coupling these statutory protections with proactive and targeted labour inspections to ensure enforcement would have a substantial impact if inspectorates were provided with sufficient resources and firewalls with immigration status were maintained. Research on wage compliance has found that employers decide on whether to follow wage regulations by balancing the expected costs of the mandated wage against those of non-compliance. ${ }^{64}$ However, the likelihood of substantial financial penalties has steadily reduced in many countries due to the heavily stretched staffing and resources of inspectorates. For example, decades of declining enforcement capacity in the

62 J Well and M Graça Prado, What Can Be Learned From Systems of Wage Protection in China, EU, US and Latin America?, Engineers Against Poverty, London, 2019.

63 B Harkins, 'Social Protection for Migrant Workers in Thailand', in J W Huguet (ed.), Thailand Migration Report 2014, UN Thematic Working Group on Migration, Bangkok, 2014.

64 B Rogers, 'Toward Third-Party Liability for Wage Theft', Berkeley Journal of Employment and Labor Law, vol. 31, issue 1, 2010, pp. 1-64, https://doi.org/10.15779/Z38RS77. 
United States means that just 1,100 investigators in the Wage and Hour Division of the Department of Labor are now responsible for protecting 135 million workers. ${ }^{65}$ The global trend of increased outsourcing of business operations and misclassification of employment status requires greater investment in labour market enforcement to support investigation and prosecution of companies seeking to evade their financial responsibilities as employers. ${ }^{66}$

Even so, the vast differences between de jure wage protections and the realities experienced by migrant workers suggest that the problem of wage theft is not likely to be resolved through government regulation alone. Changing public attitudes towards migrants in destination countries has also proven essential to reducing illegal pay practices due to the high prevalence of discriminatory views. ${ }^{67}$ Reviews of the source of these attitudes have found them to be heavily influenced by representations of migrants as a symbolic threat. ${ }^{68}$ Substantively altering this perception requires building greater understanding of the positive contributions of migrants within the public sphere and increasing social cohesion through the full inclusion of migrants in the socio-cultural life of their communities.

Labour organising has also proven to be an effective strategy for responding to wage theft against migrant workers. ${ }^{69}$ Research in Australia, where underpayment of wages is a systemic problem faced by migrant workers, has pointed to the central importance of trade unions in providing migrants with access to redress. While the study found that the number of migrant trade union members is relatively low, those who had joined a union were nearly three times as likely to pursue a case to recover wages due. ${ }^{70}$ As a supplement to more traditional approaches, worker-driven social responsibility has recently emerged as a potentially promising new model for migrant worker organising, involving legally binding agreements between workers and corporate buyers to help

65 Galvin.

66 D Weil, The Fissured Workplace: Why work became so bad for so many and what can be done to improve it, Harvard University Press, Cambridge, 2014.

67 ILO, Public Attitudes towards Migrant Workers in Japan, Malaysia, Singapore and Thailand, ILO, Bangkok, 2019.

68 J Hainmueller and D J Hopkins, 'Public Attitudes Toward Immigration', Annual Review of Political Science, vol. 17, no. 1, 2014, pp. 225-249, https://dx.doi.org/10.1146/ annurev-polisci-102512-194818.

69 E Marks and A Olsen, 'The Role of Trade Unions in Reducing Migrant Workers' Vulnerability to Forced Labour and Human Trafficking in the Greater Mekong Subregion', Anti-Trafficking Review, issue 5, 2015, pp. 111-128, https://doi. org/10.14197/atr.20121557.

70 B Farbenblum and L Berg, Wage Theft in Silence: Why migrant workers do not recover their unpaid wages in Australia, Migrant Worker Justice Initiative, Sydney, 2018. 
ensure fair wages. ${ }^{71}$ However, the significant obstacles to migrants unionising will need to be overcome, including the extensive outsourcing, informality, and precarity of their employment.

Liberalising labour migration governance regimes is another well-established measure for reducing the risk of wage theft. Eliminating tied-visas and work permits provides migrant workers with the opportunity to lodge grievances and freely pursue other employment when they are not properly remunerated for their work. Although unrestricted labour market access for migrants is a relatively rare policy position, more flexible systems in countries such as Sweden and Canada show that greater labour mobility can lower the potential for abuse without substantially depressing the wages or productivity of the labour force as a whole. Conversely, in countries like Malaysia where no changes of employment are permitted, exploitation of migrant workers continues to flourish. ${ }^{72}$

A final key means for reducing wage abuses is ensuring that fair remedies are accessible in the form of recovery of unpaid wages and financial compensation. A significant part of the reason why migrants are reluctant to participate in criminal prosecutions of trafficking cases is that they tend to be time-consuming, legalistic, and focus primarily on achieving penal sanctions against offenders, which is typically not the outcome migrants are concerned with. Research has shown that many migrants experiencing abuse seek financial remedies so that they can move on with their lives. ${ }^{73}$ In addition to ensuring timely and equitable settlements, migrant workers should be provided with compensatory amounts for the abuses suffered. Establishing substantial financial penalties for wage theft would provide a meaningful deterrent, helping to discourage repeat offenses by making them cost-prohibitive.

\section{Conclusion}

There is very limited evidence that the adoption and application of the UN Trafficking Protocol has been successful in ameliorating the scale or severity of exploitation experienced by migrant workers. Addressing the problem more effectively requires a clearer focus on the basic reasons why these abuses occur. In the vast majority of cases, it is not because of the actions of transnational criminal syndicates who abuse migrant workers as part of a clandestine enterprise, as suggested in the framing of the Protocol. Rather, it is the result of deeply inequitable power relations between migrant workers and employers,

71 M Åhlberg, 'Worker-Driven Social Responsibility: Exploring a new model for tackling labour abuse in supply chains', Focus on Labour Exploitation (FLEX), London, 2020.

72 Kouba and Baruah.

73 Harkins and Åhlberg. 
which supports the defrauding of wages as a standard function of labour migration governance regimes.

Interpreting exploitation of migrant workers as a criminal abnormality within this imbalanced system of exchange has obstructed the development of more practical and effective responses. It is no secret that the basic motivation for employment of migrants is to keep wages low in order to maximise the profitability of firms. However, this is obscured by the human trafficking framework, which identifies individual cases of extreme exploitation as unacceptable-with the effect of justifying the inequities of the global economy as a whole.

A more transformative approach to these issues cannot be limited to severe cases of exploitation that make international headlines and trigger corporate social responsibility initiatives. Instead, it would necessarily have to engage with the 'everyday' vulnerabilities to abuse that currently exist for the vast majority of migrant workers. These are principally the result of illiberal migration governance systems, exclusions from labour and social protections, lack of opportunities for worker organising, limitations in access to justice, and other structural factors that reduce the likelihood of migrants receiving their fair share of the benefits of their labour.

To be sure, an increased focus on wage theft would not provide a comprehensive response to all forms of exploitation of migrant workers covered by the frameworks of forced labour, human trafficking, and modern slavery. Ideally, expanded efforts to address wage theft would be part of a broader shift towards a labour rights approach to these issues, as there would still be a need to bring other tools to bear for abuses that fall outside the scope of wage-related matters. However, the specificity of the concept can be considered a key strength in that the identification of abuses and provision of remedies is clearer than for the existing frameworks for countering exploitation. As a result, improving the response to wage theft against migrants would lead to better working conditions for the vast missing middle who experience more commonplace forms of abuse and help to diminish the enabling environment for severe exploitation to occur.

Most importantly, the focus on a more equitable distribution of wages would redirect attention to a core issue at stake in the era of globalisation. Greater efforts to address wage theft against migrant workers would contribute to an expansion of economic and social justice for a large segment of the world's most vulnerable workers. The extent to which this will be realised is not likely to be dependent on prosecutions by specialised anti-trafficking police forces, the social responsibility of multinational corporations, or the technological solutions of Silicon Valley, but rather the ability of migrants to voice meaningful demands for fair remuneration of their work. 
Benjamin Harkins is Senior Programme Manager for the Livelihoods and Food Security (LIFT) Fund in Myanmar, where he established LIFT's Decent Work and Labour Mobility programme. Since 2008, he has worked across Southeast Asia on migration research and interventions for United Nations agencies, non-governmental organisations, and research institutes. Prior to his current role, Benjamin was Technical Officer for the ILO TRIANGLE project, where he provided assistance to governments and social partners on enhancing the protection of migrant workers’ labour rights. Email: benharkins@gmail.com 